Jurnal Bisnis dan Manajemen Volume 19, No. 2, September 2018, p. 61-71

\title{
RURAL BANK TECHNICAL EFFICIENCY IN WEST JAVA INDONESIA: EVALUATION BY OWNERSHIP AND DISTRICT
}

\author{
Mokhamad Anwar ${ }^{1}$, Layyinaturrobaniyah ${ }^{2}$, Ratna Komara ${ }^{3}$, Sulaeman Rahman Nidar ${ }^{4}$ \\ ${ }^{1234}$ Universitas Padjadjaran, Indonesia
}

\begin{abstract}
This study examines the efficiency of rural banks in West Java Indonesia in terms of technical efficiency. The analysis covers the 212 banks spread over some districts in west java province during the period 2012-2016. Those banks are under the supervision of the Financial Services Authority Regional Office of Bandung. The study employs Data Envelopment Analysis to obtain the technical efficiency of the banks over the study period. The study results suggest that there are some rural banks from certain districts enjoying most efficient; average efficiency of those banks over the study period is inclined to increase with the peak performance occurred in 2015 . The other findings suggested that capital adequacy and bank size are of essential factors determining rural bank efficiency in West Java.
\end{abstract}

Keywords: DEA, data envelopment analysis, rural bank performance

\begin{abstract}
ABSTRAK
Penelitian ini mengkaji efisiensi Bank-bank Perkreditan Rakyat (BPR-BPR) di Jawa Barat Indonesia dalam hal efisiensi teknis serta factor=factor yang mempengaruhinya. Studi mencakup data yang terdiri dari 212 bank yang tersebar di sejumlah kabupaten-kota di Provinsi Jawa Barat selama periode 2012-2016. Bank-bank tersebut berada di bawah pengawasan Otoritas Jasa Keuangan Kantor Wilayah Bandung. Data Envelopment Analysis digunakan untuk mengestimasi efisiensi teknis BPR-BPR tersebut selama periode penelitian. Hasil penelitian menunjukkan bahwa ada terdapat beberapa BPR dari kabupaten tertentu yang berkinerja paling efisien; Efisiensi rata-rata bankbank selama periode studi cenderung meningkat dengan kinerja puncak terjadi pada tahun 2015. Temuan lainnya menunjukkan bahwa kecukupan modal dan ukuran bank merupakan faktor penting dalam menentukan efisiensi bank BPR di Jawa Barat.
\end{abstract}

Kata-kata Kunci: Data envelopment analysis, efisiensi, kinerja Bank-Bank Perkreditan Rakyat

Korespondensi: Mokhamad Anwar, S.E., M.Si, Ph.D. Universitas Padjajaran. Jln. Dipati Ukur 35 Bandung 40132, Indonesia. Email: mokhamad.anwar@unpad.ac.id. 


\section{INTRODUCTION}

The role of banking in the economy is essential. Its role in collecting depository funds and allocating lending funds are critical in generating economic activities in countries. Through intermediating role, commercial banks can support financing for productive sectors in creating value added in the economy as well as assisting individual or households in consumptive purposes.

The problem that is currently faced by banking is that how wide it is reaching more considerable amount of customers in their operation. The banking industry has been growing in cities providing various services with advanced technology, but the circumstance is not similar to rural areas. Thus, the existence of rural banks is also very crucial in providing banking services for the people in the area.

In the case of Indonesia, the regulation of Indonesian banking has divided into two kinds of banks, namely commercial banks, and rural banks. The difference between the two banks is that the first is providing all of the banking services with a broader area of operations, and the latter is providing limited services with the narrower area. The other circumstance of rural banks is that they are mostly operating in districts and borough. Hence, the rural bank role is hugely demanded in the rural areas.

Considering the importance of the existence of rural banks in the Indonesian economy, it is very beneficial to examine the performance of rural banks regarding managing their operation. There have some measurements in evaluating the performance of banks, and among the two popular measurements are financial performance and frontier performance. The financial performance covers the highlights in several aspects in ratio measurement regarding bank liquidity, bank capital, and bank profitability. The popular measurement in this approach is capital adequacy, asset quality, management, earning capacity and liquidity (CAMEL). The second approach is frontier measurement concerning how efficient is a bank in processing inputs to produce outputs. This measurement can be obtained through two estimations, namely parametric and non-parametric techniques.

This study evaluates rural bank performance regarding one of the non-parametric techniques, namely data envelopment analysis (DEA). This method is chosen considering that the method is the most widely used in non-parametric techniques. The study covers the observations of rural banks located in the area supervised by the Financial Services Authority (FSA) or Otoritas Jasa Keuangan (OJK) the Regional Office of Bandung.

The importance of this study comes into several folds. First, this is the first study examining the technical efficiency of rural banks in the region and the study examining efficiency in rural banks is very rare. Second, this study is significant concerning the evaluation of the performance of banks post the crisis of 2008 is still crucial to undertake. Third, the study covers the period where 
the FSA or OJK takes over the role of banking surveillance from Central Bank of Indonesia starting in early 2013. Thus, the results of the study could be one of the indicators of the quality of surveillance of the FSA.

\section{LITERATURE REVIEW}

The previous studies concerning bank efficiency are dominantly examined to commercial banks. It is very rare that the efficiency studies are focused on rural banks. The stance is very sensible considering that the number of commercial banks is very numerous across countries and they provide banking services with the very various products with the latest technology. Then, the data of financial statements and balance sheet of the banks are relatively easy to obtain.

Meanwhile, the rural banks have characteristics of limited services provided, limited area of operation, and also a limited amount of capital invested in banks' operation. However, rural banks have also one advantage that not all commercial banks can do. The advantage resides in their ability to provide services for the segment of micro and small businesses (MSBs) where this segment of customers is critical especially in a country where the majority of the business entities are MSBs. Thus, for the case of Indonesia, the evaluation of the performance of rural banks is very important in the stake of the sustainability of their operation in servicing customers in rural areas as well as MSBs in the country.

The performance of banks can be analyzed by some approach, either parametric or nonparametric techniques, and/or financial ratio and non-financial ratio analysis. One of the most widely used methods to date is bank efficiency analysis. The study about bank efficiency have been done by many authors (Kao and Liu, 2004; Bonin et al., 2005; Mamatzakis et al., 2008; Hamiltona et.al, 2010; Haddad et al, 2011; Fethi et al, 2011; Sufian, 2010; Chunhachinda and Li, 2010; etc.).

In general, the estimation of efficiency is aimed to reveal how efficient the company or decision management unit (DMU) in using inputs to gain the outputs. The measurement can be in various terms, i.e., technical efficiency, cost efficiency, and profit efficiency. The two popular techniques in estimating efficiency are a nonparametric technique with data envelopment analysis (DEA) and a parametric technique with the stochastic frontier approach (SFA).

This study uses DEA for some reasons: the method uses mathematical linear programming then it does not need pre-specification before the estimation, the method is easy to apply and can take into accounts multiple inputs and outputs, and the method is also working well with a small sample.

Kao and Liu, 2004; Gardener et al., 2011; Haddad et al., 2011; Fethi et al., 2011; Sufian, 2010; Chunhachinda and Li, 2010; are among the authors estimating the efficiency using the DEA. Fethi (2011) estimates bank efficiency in Egypt and make the association with the policy of privatization in the country. Sufian (2010) estimates bank efficiency across some countries in Southeast Asia Nations in particular for Malaysia and Thailand and associates the effect of the 1997 Asia Financial Crisis (AFC) on the efficiency. 
Gardener et al. (2011) estimate bank efficiency of 5 South East Asian Countries post the AFC and investigate the effect of post-crisis restructuring on the efficiency estimation across the countries banks.

In the case of Indonesia, there are numerous research examining bank efficiency using the DEA undertaken by many authors to date. Among the authors, i.e., Haddad et al. (2011), Suzuki and Sastrosuwito (2011), Anwar (2015). Hadad et al. (2011) employ non-parametric slack-based DEA to examine the profit-based technical efficiency and productivity of listed Indonesian banks over the period 2003-2007. Suzuki and Sastrosuwito (2011) investigate the efficiency of Indonesian commercial banks during the period 1994-2008. Anwar (2015) estimates bank efficiency using DEA over all commercial banks in Indonesia during the period 2002-2010.

Hadad et al. (2011) reveal that the average efficiency of Indonesian listed banks is in the variation of "between 0.34 to 0.97 " over the study period and the score of efficiency has a positive association share price and return on equity in all models.

Suzuki and Sastrosuwito (2011) make a comparison concerning the efficiency level of Indonesian banks in terms of different ownership over the period of 1994-2008. By using the sample of 70 banks in Indonesia, they find that the average efficiency of Indonesian banks over the period was 0.866 with the most efficient banks is the group of government-owned banks.

Anwar (2015) finds that the technical efficiency of Indonesian banks has tended to decline over the period 2002-2010. The global crisis of 2007-2008 has also affected the efficiency of Indonesian banks albeit the magnitude is not significant.

Those authors and some other authors only examine the efficiency of Indonesian commercial banks suggested that the banks are large in assets and equity, providing services not only micro and small businesses but also medium enterprises and large enterprises. The evaluation in terms of bank technical efficiency for rural banks is still very rare to find in literature. Thus this study comes to fill the gap.

\section{METHODS}

The study employs purposive sampling of data with the criteria: (1) the banks are rural banks in the area of surveillance of FSA regional office of Bandung, (2) the data of banks should have completed during the period of observation, 20122016.

The study includes the data of 212 rural banks covering 17 districts in the area of surveillance of Otoritas Jasa Keuangan (Financial Services Authority/FSA), the regional office of Bandung. The rural banks consist of 17 Local Government-Owned Banks (LGB) and 195 private banks (PB). The data are obtained from the FSA regional office of Bandung.

In accordance with the study purposes, the study employs Data Envelopment Analysis (DEA) in estimating the efficiency of the banks with the extensive analysis revealing the average technical efficiency of all observed banks, average efficiency by ownership, and average efficiency by the 
district. The study also shows the name of banks in the frontier during the consecutive years of observations.

The study employs DEA with the model specification as follows: (1) the study uses the intermediation approach in determining inputs and outputs. Thus, deposits have been considered and include as one of the inputs along with net fixed assets, and general and administrative expenses. Besides, the study chooses loans, placement, and operating income as outputs, (2) The study uses the assumption of a variable return to scale (VRS) as one of the bases in estimating efficiency.

In the second stage of analysis, this study provides an extensive analysis by revealing the determinant of the technical efficiency of the banks over the study period. The study employs Tobit regression estimation considering the format of the dependent variable is within 0 and 1 . Thus the censored model of regression is used.

The model of the regression is as follows:

$T E_{i t}=\mathrm{b}_{0}+\mathrm{b}_{1} C A R_{i t}+\mathrm{b}_{2} N P L_{i t}+\mathrm{b}_{3} R O A_{i t}+\mathrm{b}_{4}$ $O C_{-} O R_{i t}+\mathrm{b}_{5} L D R_{i t}+\mathrm{b}_{6} L N T A_{i t}+\varepsilon_{i t}$ Where:
$T E_{i t} \quad$ Technical efficiency of $i$-th bank in period-t derived from the DEA technique.

$C A R_{\text {it }}$ Capital adequacy ratio is a representative of bank capital. Capital adequacy ratio (CAR) is measured by calculating bank capital divided by risky-weighted assets.

$N P L_{i t} \quad$ Non-performing loans (NPL) is assigned to signify bank risk. NPL is measured by dividing all nonperforming loans over all bank loans.

$R O A_{i t} \quad$ Return on assets (ROA) is assigned to represent the bank's profit. ROA is obtained by dividing net income over total assets.

$O C_{-} O R_{i t}$ Operating Cost to Operating Revenue (OC_OR) as the representation of bank operating cost consumption. OC_OR is obtained by dividing total operating costs over total operating revenue of banks.

$L D R_{i t} \quad$ Bank liquidity means the ability of a bank to cover its short-term liabilities. Loans to deposits ratio (LDR) is the proxy for bank liquidity.

$L N T A_{i t}$ Natural logarithm of total assets (LNTA) as a proxy for the bank's size.

$\varepsilon_{i t} \quad$ Error term 
Jurnal Bisnis dan Manajemen Volume 19, No. 2, September 2018, p. 61-71

\section{RESULTS AND DISCUSSION}

Based on the estimation of technical efficiency across all observed rural banks in West Java, it is revealed that the average of technical efficiency is tended to fluctuate over the five years of observation.

Figure 1 Average technical efficiency across all observed rural banks (2002-2016)

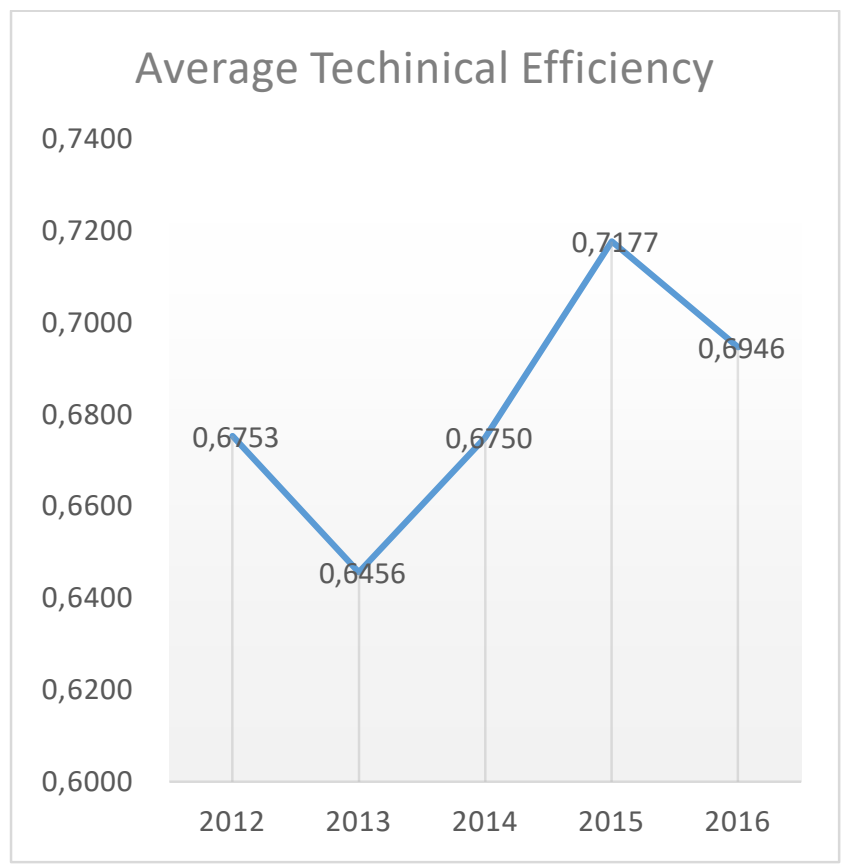

Source: Processed data (2018)

The above figure shows that the average technical efficiency of the rural banks tends to increase over the period 2012-2016 with the peak performance occurred in 2015. The average efficiency over the period is 0.6816 with the lowest happened in $2013(0.6456)$ and the highest is occurred in 2015 (0.7177). The increasing trend of the score of technical efficiency of those rural banks indicates that they have been operating in a better way of utilizing their inputs in producing outputs. In accordance with the model employed, it is meaning that in generating loans, placement and operating income as outputs of bank operation, those rural banks have been utilizing deposits, general and administrative expenses with lower proportions overtime during the period 2012-2016.

\section{Figure 2 Average technical efficiency by different ownership of the rural banks (2002-2016)}

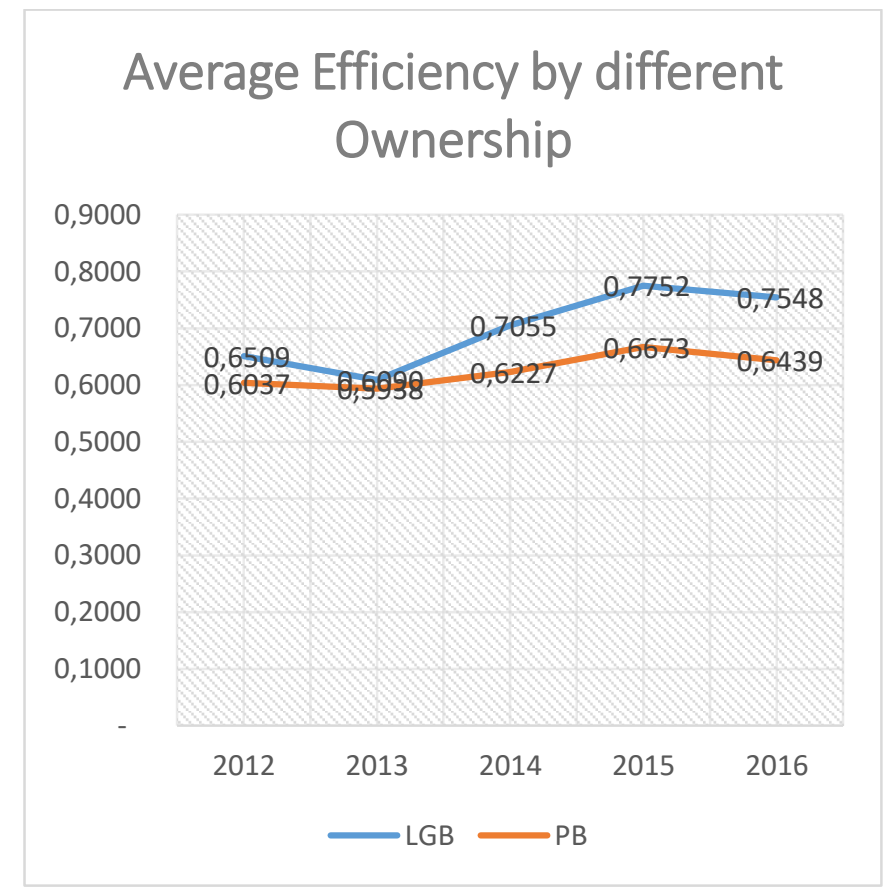

Source: Processed data (2018)

Figure 2 demonstrates the different performance of the banks by different ownership over the study period. It is revealed that the average efficiency of the local government banks (LGB) has better performance than their peers from the private banks. The average efficiency of those banks is inclined to increase over the period of observations. The average efficiency of the LGB is 0.6991, a bit higher than those of the Private Banks (PB) which is recorded at 0.6263. The results indicate that LGB has been successful in building 'trade-mark,' that as a government-owned bank, it is assumed to be stronger than their peers from 
private banks since the government will always support the banks particularly in terms of the injection of equity. The other reason behind the success of the banks is that they are usually utilizing the civil servants or government officials to be loyal customers both in funding and lending facilities provisions.

Figure 3 Average Technical Efficiency of the Rural Banks (2002-2016)

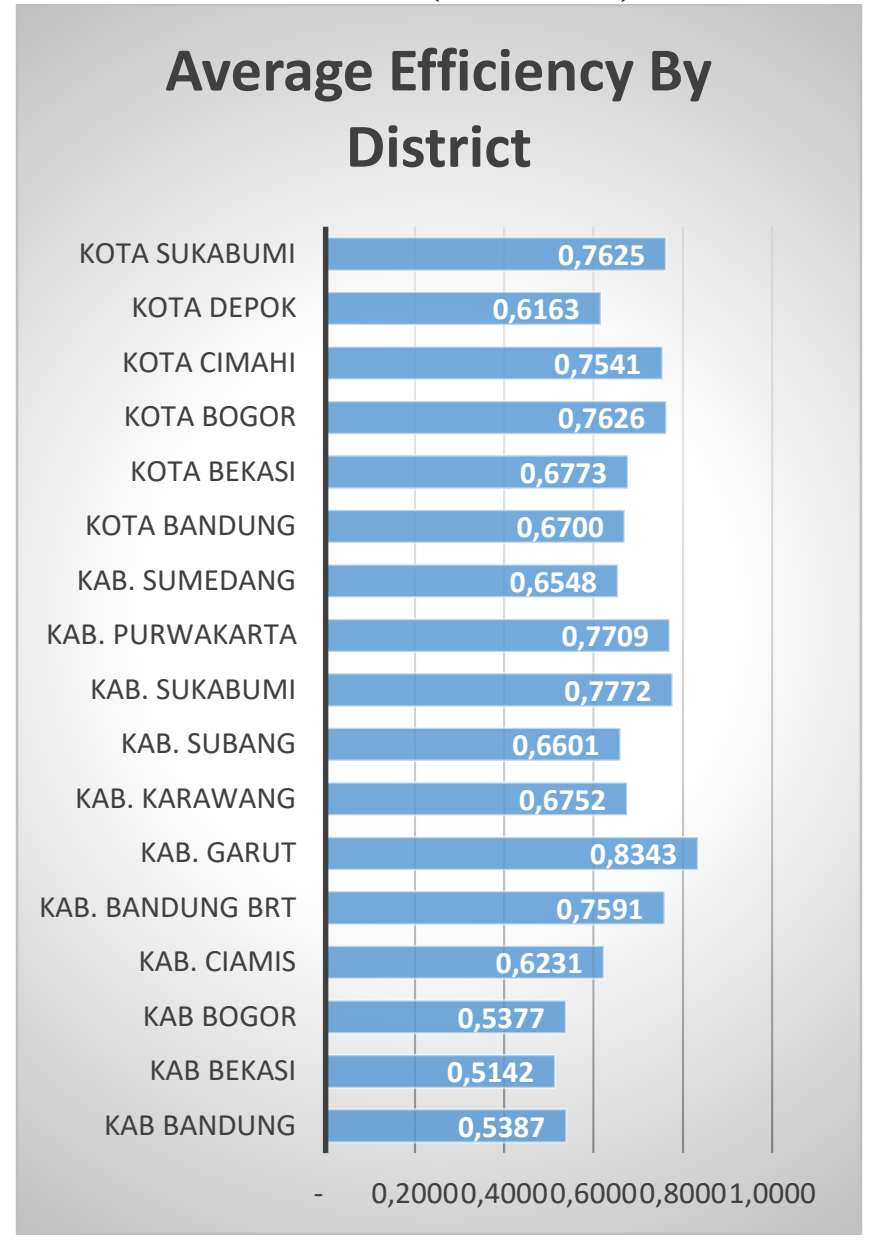

Source: Processed data (2018)

Meanwhile, Figure 3 demonstrates the average efficiency across the observed banks evaluated based on different districts in West Java. The figure indicates that the attainment of rural banks' efficiency in the District of Garut is the highest over the period with the average efficiency attainment of 0.8343 . It is then followed by Kabupaten Sukabumi dan Kabupaten Purwakarta.
Meanwhile, the rural banks Kabupaten Bekasi experience the lowest experience over the period with the average of 0.5142 .

In the evaluation of the rural area performance, it is also beneficial to compare the performance of banks from different districts regarding how many years they are experiencing technical efficient over the study period. From the criteria, it is revealed that there are some districts attaining technical efficient in all consecutive years, and there are efficient in one, two, three and four years of observation. These data below show the configuration of the districts' rural banks' efficiency over the study period:

\section{Table 1 Rural Banks in Frontier}

\begin{tabular}{|c|c|c|c|c|c|}
\hline No & District & $\begin{array}{c}\text { Obs } \\
.\end{array}$ & $\begin{array}{l}\text { 5_ti } \\
\text { mes }\end{array}$ & $\begin{array}{l}\text { 4_ti } \\
\text { mes }\end{array}$ & $\begin{array}{l}\text { 3_ti } \\
\text { mes }\end{array}$ \\
\hline 1 & $\begin{array}{l}\text { Kab } \\
\text { Bandung }\end{array}$ & 19 & 0 & 1 & 1 \\
\hline 2 & Kab Bekasi & 25 & 0 & 0 & 2 \\
\hline 3 & Kab Bogor & 23 & 0 & 0 & 1 \\
\hline 4 & $\begin{array}{l}\text { Kab. } \\
\text { Ciamis }\end{array}$ & 4 & 0 & 0 & 0 \\
\hline 5 & $\begin{array}{l}\text { Kab. } \\
\text { Bandung } \\
\text { Brt }\end{array}$ & 6 & 1 & 1 & 0 \\
\hline 6 & Kab. Garut & 3 & 0 & 0 & 2 \\
\hline 7 & $\begin{array}{l}\text { Kab. } \\
\text { Karawang }\end{array}$ & 14 & 2 & 1 & 1 \\
\hline 8 & $\begin{array}{l}\text { Kab. } \\
\text { Subang }\end{array}$ & 9 & 1 & 0 & 0 \\
\hline 9 & $\begin{array}{l}\text { Kab. } \\
\text { Sukabumi }\end{array}$ & 5 & 1 & 0 & 1 \\
\hline 10 & $\begin{array}{l}\text { Kab. } \\
\text { Purwakarta }\end{array}$ & 2 & 0 & 1 & 0 \\
\hline 11 & $\begin{array}{l}\text { Kab. } \\
\text { Sumedang }\end{array}$ & 3 & 0 & 0 & 0 \\
\hline 12 & $\begin{array}{l}\text { Kota } \\
\text { Bandung }\end{array}$ & 25 & 3 & 0 & 2 \\
\hline 13 & $\begin{array}{l}\text { Kota } \\
\text { Bekasi }\end{array}$ & 35 & 1 & 2 & 2 \\
\hline 14 & Kota Bogor & 6 & 0 & 0 & 1 \\
\hline 15 & $\begin{array}{l}\text { Kota } \\
\text { Cimahi }\end{array}$ & 4 & 0 & 1 & 0 \\
\hline 16 & $\begin{array}{l}\text { Kota } \\
\text { Depok }\end{array}$ & 27 & 0 & 0 & 1 \\
\hline \multirow[t]{2}{*}{17} & $\begin{array}{l}\text { Kota } \\
\text { Sukabumi }\end{array}$ & 2 & 0 & 1 & 0 \\
\hline & Total & 212 & 9 & 8 & 14 \\
\hline
\end{tabular}

Source: Observed Data (2018) 
Jurnal Bisnis dan Manajemen Volume 19, No. 2, September 2018, p. 61-71

The table shows the number of banks in the frontier over the years observed. It is shown that Kota Bandung has 3 (three) banks which operate technically efficient over all consecutive years. The efficient banks are PT. BPR Daya Lumbung Asia, PT. BPR Karyajatnika Sadaya, and PT. BPR Kertamulia. The findings demonstrate that because they are located in a big city, the competition of the banks is very high, not only with other rural banks but also with commercial banks, then the level of efficiency of the rural banks in the area is increasing.

\section{Table 2 Name of Rural Banks in Frontier}

\begin{tabular}{|c|c|c|c|}
\hline No & $\begin{array}{c}\text { Name of } \\
\text { Banks }\end{array}$ & Ownership & District \\
\hline 1 & $\begin{array}{l}\text { PT. BPR } \\
\text { Anugerah } \\
\text { Multi Dana }\end{array}$ & $\mathrm{PB}$ & Kab. Karawang \\
\hline 2 & $\begin{array}{l}\text { PT. BPR } \\
\text { Karya } \\
\text { Utama Jabar }\end{array}$ & PB & Kab. Subang \\
\hline 3 & $\begin{array}{l}\text { PT. BPR } \\
\text { Nehemia }\end{array}$ & PB & Kab. Bdg Barat \\
\hline 4 & $\begin{array}{l}\text { PT. BPR } \\
\text { Pantura } \\
\text { Abadi }\end{array}$ & PB & Kab. Karawang \\
\hline 5 & $\begin{array}{l}\text { PT. BPR } \\
\text { Aditama } \\
\text { Arta }\end{array}$ & PB & Kota Bekasi \\
\hline 6 & $\begin{array}{l}\text { PT. BPR } \\
\text { Daya } \\
\text { Lumbung } \\
\text { Asia }\end{array}$ & PB & Kota Bandung \\
\hline 7 & $\begin{array}{l}\text { PT. BPR } \\
\text { Karyajatnika } \\
\text { Sadaya }\end{array}$ & PB & Kota Bandung \\
\hline 8 & $\begin{array}{l}\text { PT. BPR } \\
\text { Kertamulia }\end{array}$ & PB & Kota Bandung \\
\hline 9 & $\begin{array}{l}\text { PT. BPR } \\
\text { Supra } \\
\text { Artapersada }\end{array}$ & PB & Kab. Sukabumi \\
\hline
\end{tabular}

Sources: Observed Data (2018)

Table 2 exposes the name of rural banks in the frontier over the study period. Of all efficient banks, there have some banks come from other districts than Kota Bandung (i.e., BPR Anugerah
Multi Dana, BPR Karya Utama, BPR Nehemia, BPR Pantura Abadi, BPR Aditama Arta, and BPR Supra Arta Persada). These findings show that it is possible for rural banks operated in districts outside big cities to be a best-performing bank.

It is also very beneficial to be revealed that the results of the study are in accordance with or coincide with the evaluation from another party. For instance, some banks measured as efficient banks in this study (i.e. BPR Karya Utama Jabar and BPR Karyajatnika Sedaya are frequently awarded as best rural banks by one of the most popular banking magazines in Indonesia).

However, it is more difficult for rural banks to be more efficient than those of their peers from commercial banks considering that the price of funds exerted by rural banks are more expensive than that of commercial banks and this stance would affect their lower ability in facing the competition. The other factor supporting the argument is that the banking technology owned by rural banks are less sophisticated than their peers from commercial banks.

\section{Determinants of Technical Efficiency of Rural Banks in West Java}

This study also extends the analysis by examining the determinants of rural bank efficiency during the period. This is to identify what factors are dominantly affecting bank efficiency in terms of bank characteristics in particular. 
Jurnal Bisnis dan Manajemen Volume 19, No. 2, September 2018, p. 61-71

Table 3 Determinants of Rural Bank Efficiency in West Java

\begin{tabular}{lll}
\hline \multicolumn{1}{c}{ VARIABLES } & $\begin{array}{c}(\mathbf{1}) \\
\text { tobit_reg }\end{array}$ & $\begin{array}{c}(\mathbf{2}) \\
\text { tobit_reg }\end{array}$ \\
car & $\begin{array}{l}0.325^{* * *} \\
(0.0383)\end{array}$ & \\
npl & $0.107^{*}$ & \\
& $(0.0628)$ & \\
roa & -0.0334 & \\
& $(0.106)$ & \\
oc_or & 0.0211 & \\
& $(0.0245)$ & \\
ldr & $0.0756^{*}$ & \\
& $(0.0390)$ & \\
ln_ta & $0.128^{* * *}$ & \\
& $(0.0111)$ & \\
Constant & $-1.676^{* * *}$ & $0.178^{* * *}$ \\
& $(0.202)$ & $(0.0108)$ \\
& & \\
Observations & 1,060 & 1,060 \\
Number & of & \\
bank_id & 212 & 212 \\
\hline
\end{tabular}

Standard errors in parentheses

$* * * \mathrm{p}<0.01, * * \mathrm{p}<0.05, * \mathrm{p}<0.1$

The table 3 above demonstrates the variables determining rural bank efficiency in West Java over the period 2012 to 2016. Among all variables included in the model, it is found that Capital Adequacy (CAR) and the natural logarithm of Total Assets (LN_TA) are the significant variables influencing rural bank efficiency in West Java. It is very sensible finding that CAR and LN_TA affecting rural bank efficiency considering that rural banks are different with the other commercial banks in terms of the scope of region attached in their operation and the quality of risk regarding their lending facility.

As we are concerned, that the scope of operations of rural banks are in rural areas and the majority of their lending facility is focused on the segment of micro and small businesses. As Berger
(2001) stated that the lending facility provided for micro and small businesses is higher than another segment of loans considering that the facility should prepare more relationship officers than those of the other loan segment.

The other argument that could be remarked regarding the significant factor is that the prevailing of the Structure-Conduct-Performance in the sense that as bigger the size of the bank, the bank will enjoy economies of scale that this would ultimately enhance the bank performance. This argument supported the finding that LN_TA has influenced rural bank efficiency in West Java over the period 2012 to 2017.

\section{CONCLUSION}

This study examines the technical efficiency of rural banks in the area of districts covered under the surveillance of the Financial Services Authority (FSA) or Otoritas Jasa Keuangan (OJK) the regional office of Bandung. The study includes 212 rural banks over 17 districts in West Java Province from 2012 to 2016.

The Data envelopment analysis (DEA) is employed in this study to reveal the technical efficiency level of those banks over the period. The study also provides an extensive analysis by examining the determinants of rural banks' efficiency over the period.

The results of the study find that the average efficiency of West Java's rural banks over the study period is tending to increase with the average attainment of technical efficiency of 0.6816 .

It is also revealed that the average efficiency of the local government banks (LGB) has better 
Jurnal Bisnis dan Manajemen Volume 19, No. 2, September 2018, p. 61-71

performance than their peers from the private banks. The average efficiency of those banks is inclined to increase over the period of observations. The average efficiency of the LGB is 0.6991 , a bit higher than those of the Private Banks (PB) which is recorded at 0.6263 .

Across all observed banks, it is revealed that the rural banks from District of Garut are experiencing the highest average technical efficiency and the rural banks from Kabupaten Bekasi experience the lowest average technical efficiency over the period. The findings from the regression model show that Capital Adequacy (CAR) and the natural logarithm of Total Assets (LN_TA) are the significant variables influencing rural bank efficiency in West Java over the period. These findings suggest that the adequacy of capital and the size of the banks are important factors determining the technical efficiency of rural banks in West Java over the period.

\section{REFERENCES}

Anwar, M. (2015). Bank Efficiency and Lending Propensity: Evidence from Commercial Banks in Indonesia. Ph.D. Thesis, University of Leicester, UK.

Berger, A.N., Klapper, L.F., \& Udell, G.F. (2001). The Ability of Banks to Lend to Informationally Opaque Small Businesses. Journal of Banking \& Finance, 25: 2127-2167.

Berger, A. N., Hasan, I., \& Zhou, M. (2010). The Effects of Focus versus Diversification on Bank Performance: Evidence from Chinese Banks. Journal of Banking \& Finance, 34: 1417-1435.

Berger, A.N., \& Black, L.K. (2011). 'Bank Size, Lending Technologies, and Small Business Finance'. Journal of Banking \& Finance, 35: 724-735.
Bonin, J.P., Hasan, I., \& Wachtel, P. (2005). Bank Performance, Efficiency and Ownership in Transition Countries. Journal of Banking \& Finance, 29: 31-53.

Casu, B., \& Molyneux, P. (2003). A comparative study of efficiency in European Banking. Applied Economics, 35: 1865-1876.

Chan, S.G., \& Karim, M.Z.A. (2010). Bank Efficiency and Macroeconomic Factors: the Case of Developing Countries. Global Economic Review, 39:3, 269-289.

Chang, C.E., Hasan, I., \& Hunter, W. (1998). Efficiency of multinational banks: An empirical investigation. Applied Financial Economics, 8: 689-696.

Kao, C., \& Liu, S.T. (2004). Predicting Bank Performance with Financial Forecast: A Case of Taiwan Commercial Banks. Journal of Banking and Finance, 28: 2353-2368.

Chunhachinda, P., \& Li, L. (2010). Efficiency of Thai Commercial Banks: Pre-vs.Post-1997 Financial Crisis. Review of Pacific Basin Financial Markets and Policies (Vol. 13, No. 3): 417-447.

Coelli, T.J., Rao, D.S.P., O’Donnell, C.J., \& Battese, G.E. (2005). An Introduction to Efficiency and Productivity Analysis: Second Edition. Springer Science and Business Media, LLC.

Fethi, M.D., Shaban, M., \& Jones, T.W. (2011). Liberalisation, Privatisation, and the Productivity of Egyptian banks: A Non-parametric Approach. The Service Industries Journal, 31:7, 1143-1163.

Gardener, E., Molyneux, P., \& Nguyen, L. H. (2011). Determinants of efficiency in Southeast Asian banking. The Service Industries Journal, 31(16), 2693-2719.

DOI: $10.1080 / 02642069.2010 .512659$

Hadad, M.D., Hall, M.J.B., Kenjegalieva, K.A., Santoso, W., Satria, R., \& Simper, R. (2011). Banking Efficiency and Stock Market Performance: An Analysis of Listed Indonesian Banks. Rev Quant Finan Acc, 37:1-20.

Hamiltona, R., Qasrawib, W. \& Al-jarrah, I.M. (2010). Cost and Profit Efficiency in the Jordan Banking Sector 1993-2006: A Parametric Approach. International Research Journal of Finance and Economics, ISSN 1450-2887 Issue 56. 
Jurnal Bisnis dan Manajemen Volume 19, No. 2, September 2018, p. 61-71

Kao, C., \& Liu, S-T. (2004). Predicting bank performance with financial forecasts: A case of Taiwan commercial banks. Journal of Banking \& Finance, 28: 2353-2368.

Mamatzakis, E, Staikouras, C., \& Filippaki, A.K. (2008). Bank Efficiency in the New European Union Member States: Is There Convergence?. Int'l Review of Financial Analysis, 1156-1172.

Shaban, M (2008). Financial Liberalisation, Privatisation, and Productivity in Banking: The Experience in Two Emerging Economies. Ph.D. Thesis, School of Management, University of Leicester, UK.

Shin, D.J.,\& Kim, B.H. S. (2011). Efficiency of the Banking Industry Structure in Korea. Asian Economic Journal (Vol. 25 No. 4), 355-373.

Sufian, F. (2010). The Impact of the Asian financial crisis on bank efficiency: the 1997 experience of Malaysia and Thailand. Journal of International Development, 22: 866-889.

Sufian, F. (2011). Benchmarking the efficiency of the Korean banking sector: a DEA approach. Benchmarking: An International journal (Vo. 18 No. 1), pp. 107-127.

Suzuki, Y., \& Sastrosuwito, S. (2011). Efficiency and Productivity Change of the Indonesian Commercial Banks. International Conference on economics, Trade and development IPEDR (Vol.7), IACSIT, Singapore. 